\title{
Understanding Contaminants Associated with Mineral Deposits
}

\begin{abstract}
Recoln
(USGS) have resulted in substantial progress in understanding the processes that control

- the release of metals and acidic waters from inactive mines and mineralized areas,

- the transport of metals and acidic waters to streams, and

- the fate and effect of metals and acidity on downstream ecosystems.
\end{abstract}

\section{Overview}

The potential environmental effects associated with abandoned and inactive mines, resulting from the complex interaction of a variety of chemical and physical processes, is an area of study that is important to the USGS Mineral Resources Program. Understanding the processes responsible for the environmental effects of abandoned and inactive mines is also of interest to a wide range of stakeholders, including both those responsible for managing lands with historical mined areas and those responsible for anticipating environmental consequences of future mining operations. The recently completed USGS project entitled "Process Studies of Contaminants Associated with Mineral Deposits" focused on abandoned and inactive mines and mineralized areas in the Rocky Mountains of Montana, Colorado, New Mexico, Utah, and Arizona, where there are thousands of abandoned mines.

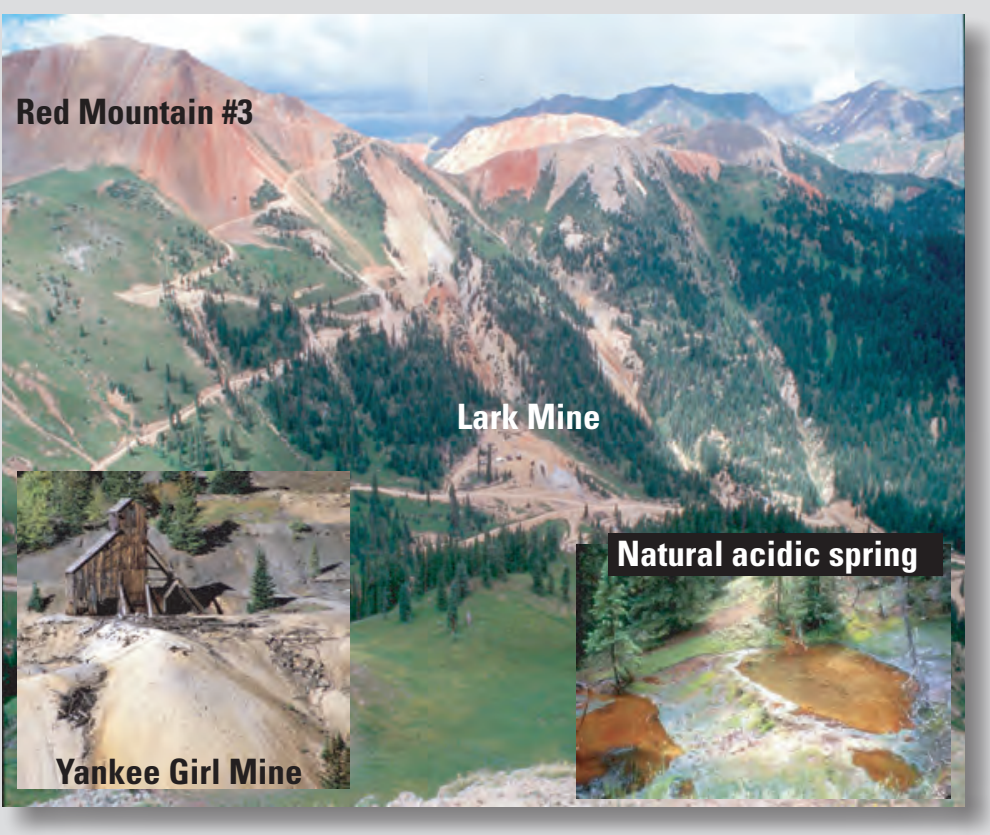

Photo 1. In the Red Mountain Mining District, Colorado, a complex mixture of source material for metals and acidity includes abandoned gold, silver, copper, and lead mines and the surrounding mineralized but unmined areas.

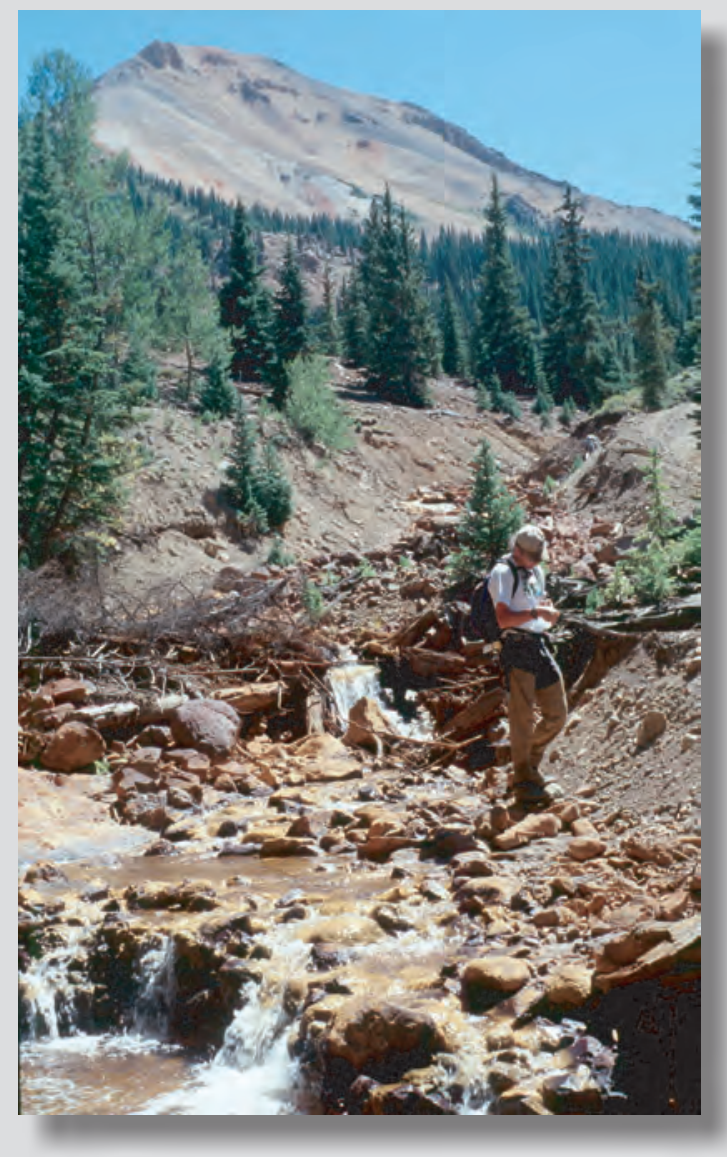

Photo 2. Red Mountain Creek, within the Red Mountain Mining District, receives waters from mined areas as well as waters that are naturally acidic and metal rich.

Results from these studies provide new information that advances our understanding of the physical and biogeochemical processes responsible for the mobilization, transport, reaction, and fate of potentially toxic elements in mineralized near-surface systems and their effects on aquatic and riparian habitat. The significant chemical elements of interest include aluminum, arsenic, cadmium, copper, iron, lead, and zinc. These interdisciplinary studies provide the basis for scientific decision making and remedial action by local, State, and Federal agencies charged with minimizing the impacts of potentially toxic elements on the environment.

Current USGS research highlights the importance of understanding (1) the geologic sources of metals and acidity, as well as the geochemical reactions that release them from their sources; (2) the pathways that facilitate transport from those sources; and (3) the processes that control the fate of the elements once released from the sources. Experts in the fields of economic geology, structural geology, mineralogy, geophysics, 
geochemistry, hydrology, ground-water modeling, microbiology, and toxicology came together for a series of studies that address these relationships on scales ranging from the watershed to the microscopic. Highlights include:

- Microscopic studies and laboratory experiments on mine waste material to understand the complex relationship between primary and secondary minerals and the release and transport of metals;

- Laboratory experiments designed to document the role microbial communities play in the release and concentration of metals in mine-waste rock;

- Design, testing, and screening of protocols to identify potential toxicity associated with leaching and weathering of mine waste rock;

- Detailed studies of existing deep exploration boreholes in the mineralized but unmined Handcart Gulch area (Colo.) to identify the link between the physical and mineralogical properties of the sulfide-bearing rock and the release of metals and acidity into a receiving stream;

- Multidisciplinary studies of bedrock geology including field mapping, geophysical surveys, mineralogical determinations, and laboratory leaching experiments to identify favorable rock units for use in remediation projects;

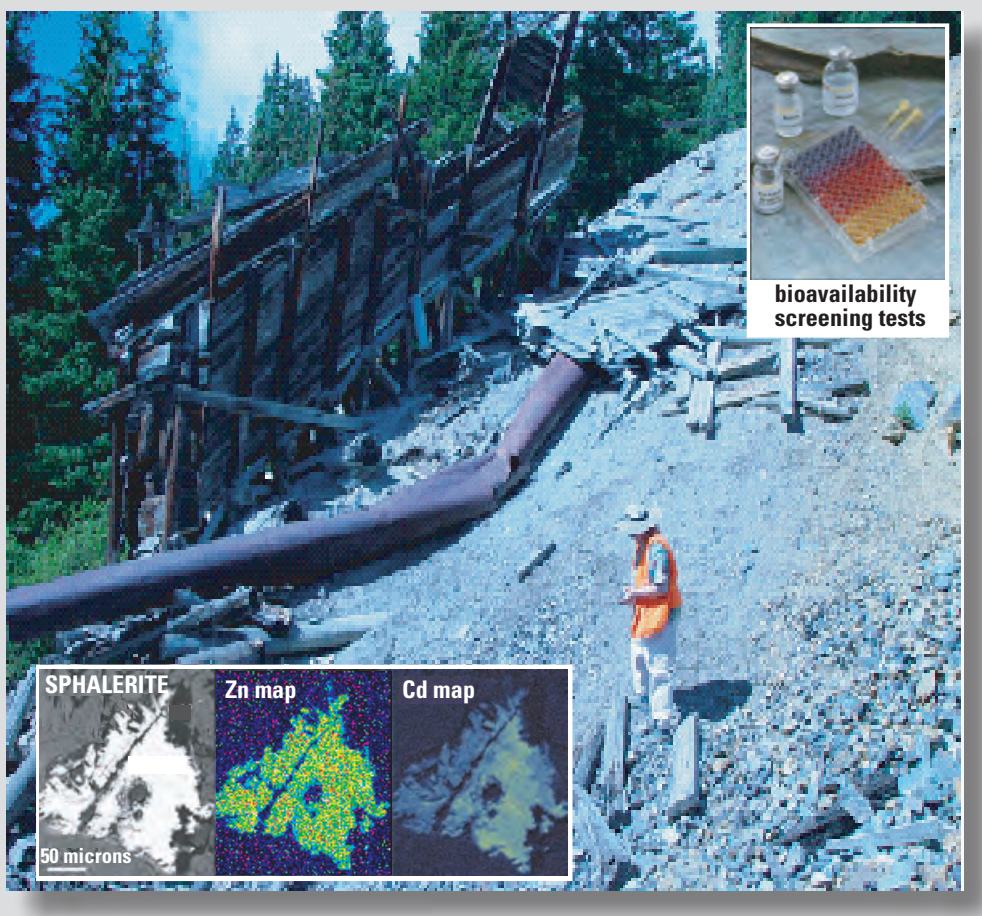

- Multidisciplinary studies of a highly mineralized and extensively mined alpine catchment, Prospect Gulch, Colo., to identify mining and natural sources of metals and acidity to receiving streams;

- Use of geophysical techniques to identify water pathways through wasterock piles;

- In extensively altered areas, using Airborne Visible/Infrared Imaging Spectrometer (AVIRIS) data and geologic mapping to document the spatial extent of mineralized rock; and

- Analysis of time-series data to assess downstream effects of mine-site remediation efforts and the subsequent recovery of aquatic ecosystems.

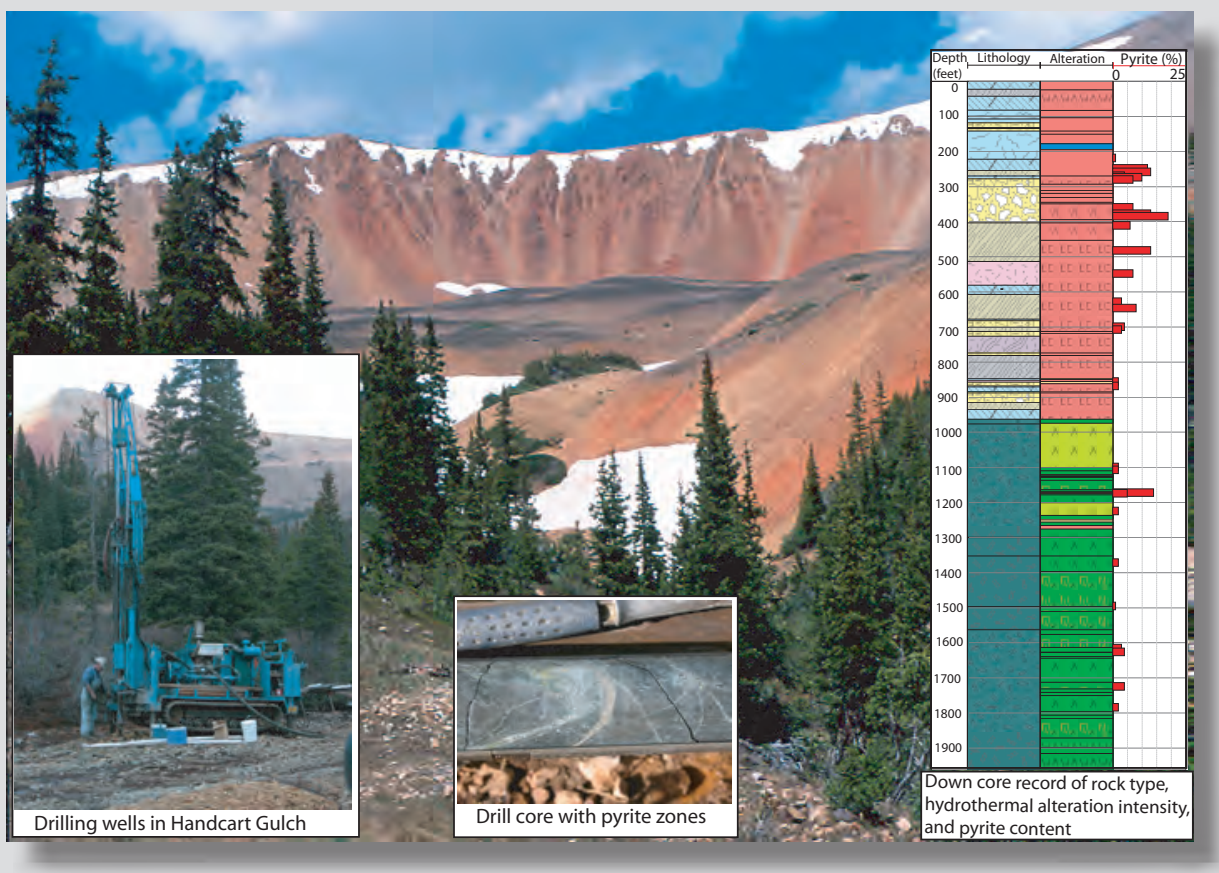

Figure 1. Geologist conducting field studies of mine-waste material. Samples used for detailed microchemical analyses to determine mineralogical and chemical variability and for developing metal bioavailability screening tests.

\section{Sources of Metals and Acidity}

Metal and acidity are released from both abandoned mines and mineralized but unmined areas as water and oxygen react with sulfide minerals. Weathering of pyrite, a common iron sulfide mineral $\left(\mathrm{FeS}_{2}\right)$, produces iron and sulfuric acid, which in turn can leach major elements such as aluminum, calcium, and magnesium and trace elements such as copper and zinc from surrounding rocks. Newly-formed acidic, metal-rich waters can then flow into receiving streams. Waste rock, material from the mine site that is not processed for ore or is left over after ore processing, is generated during mining operations and usually stored on site. Waste rock is a complex mixture of rocks and minerals from the mine workings that has been broken up to varying degrees, from a fine powder to the size of boulders. In most cases, mine-waste material is stored on the ground surface and is susceptible to weathering. U.S. Geological Survey research has focused on understanding the generation of metals and acidity from waste-rock piles (fig. 1) and from mineralized but unmined areas (fig. 2).

In order to examine the processes that control acid generation and metal release from mine-waste material, samples were collected from different geologic settings and examined in the laboratory for geochemical and mineralogical changes related to weathering of the mine-waste piles. Methods such as quantitative X-ray diffraction, bulk chemical analysis, optical mineralogy, microanalysis

Figure 2. Integrated studies of Handcart Gulch document a link between acidic, metal-rich ground water and the intensity of hydrothermal alteration and pyrite content. 
techniques, acid-base accounting,

leaching techniques, microbial assays, and toxicological modeling were employed to understand the complex mixture of primary and secondary minerals as well as the effects of seasonal, water-soluble precipitates. The trace mineral content of primary minerals can be variable, and the weathering of wasterock material results in changes in grain size and texture and the potential for secondary minerals to coat primary minerals all of which adds to the complexity of the study. Standard methods for waste-rock pile sampling and waste-rock material leaching experiments assessing the toxicology of waste-rock material were developed, tested, and presented at international meetings and workshops.

In Colorado, one example of a mineralized but unmined alpine catchment can be found in Handcart Gulch (fig. 2), a watershed that lies along the Continental Divide and is underlain by a low-grade copper-molybdenum deposit. The area provides a unique opportunity to study natural sources of metals and acidity and their movement through the surface and ground water in the fragile alpine watershed (Caine and others, 2006). Cooperators provided USGS personnel with access to four deep mineral exploration wells (365-1,065 m) in the upper part of the catchment. Geophysical borehole logging of the wells provided characteristics of the physical properties of the rocks, mineralogical studies contributed to an understanding of the primary and secondary sources of metals, ground-water chemistry determined the concentration of metals and acidity released from the weathering of mineralized rocks, and ground-water ages provided constraints on ground-water transport rates through the upper watershed.

\section{Pathways that Transport Metals and Acidity}

An important aspect in evaluating the potential environmental effects of mineralized areas and abandoned mines is the determination of pathways and fluxes of metals from their sources to the receiving streams and ground water. Integration of geological, geochemical, and geophysical techniques led to substantial advances in our understanding of ground-water flow in alpine basins and waste-rock piles.

Integrated geophysical and geochemical studies were used by USGS scientists to identify ground-water pathways through a typical waste-rock pile at the Waldorf mine in central Colorado (fig. 3).
Electromagnetic surveys and resistivity profiles are two complimentary geophysical methods that measure how conductive the underlying material is and help delineate water flowpaths. Using these geophysical techniques, two primary sources of water were identified as entering the waste-rock pile: (1) water from the mine adit infiltrates the upper part of the pile and (2) ground water from shallow fracture-flow in bedrock infiltrates at the bedrock interface (McDougal and Wirt, 2007). Understanding the water pathways through the waste-rock pile is critical to understanding the source and movement of metals and acidic water that, visible as metalrich seeps, represent potential environmental challenges.

\section{Fate of Released Metals}

After metals and acidity have been mobilized from their sources and transported to receiving streams, determining their fate and effect on the ecosystem is an important aspect of addressing abandoned mines and mineralized but unmined areas. To determine the fate of potentially toxic metals, USGS research included detailed stream sampling events to determine where metal-rich waters enter receiving streams, geochemical modeling of water chemistry to determine the potential toxicity of different waters, and post-remediation chemical analysis to evaluate changes in environmental indicators.

Historically, water-quality criteria, as pertaining to aquatic organisms, have been based on the total dissolved concentration of a metal adjusted for hardness. In concert with recent advances in understanding toxicity of metals that focus on the importance of the bioavailable fraction of the metal, project studies have utilized complete water chemistry and speciation calculations to evaluate processes that control variations in the bioavailable fraction of metals in waters draining mined and mineralized rock. The Biotic Ligand Model, which is a computational approach used to determine metal speciation and potential acute toxicological effects developed by Allen (2002), has been used to determine the effects of watershed lithology on potential metal toxicity in streams.

The effect of metals and acidity on ecosystems has been closely monitored by mining companies, land managers, and government regulators involved in mine sites. Different factors contribute to the movement of metals and acidic water through our environment. Examples of the effects of these factors can be found at three different locations: (a) the Morenci copper mine in Arizona is set in a relatively simple hydrogeologic setting; (b) the Boulder River basin, Montana, represents a slightly more

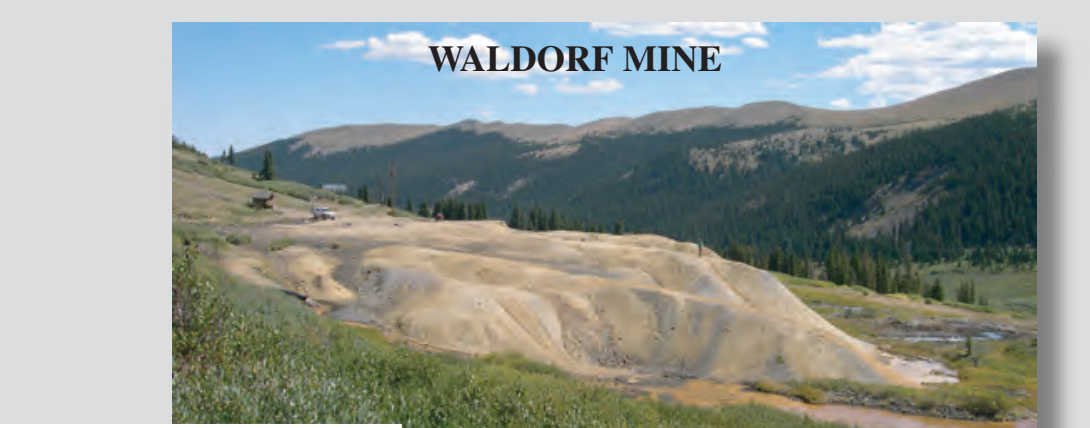

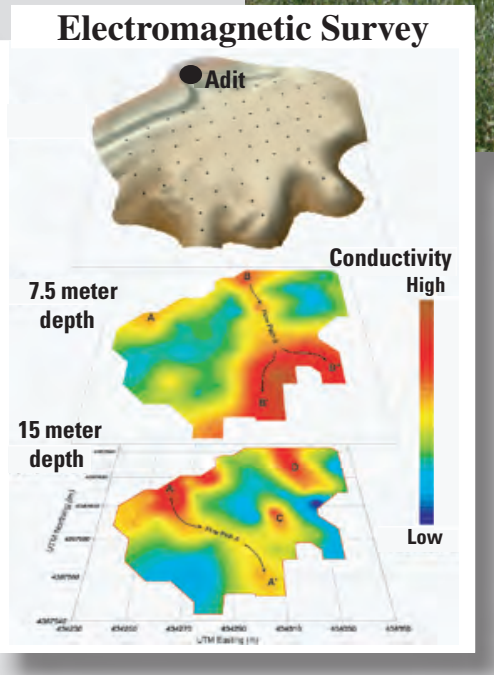
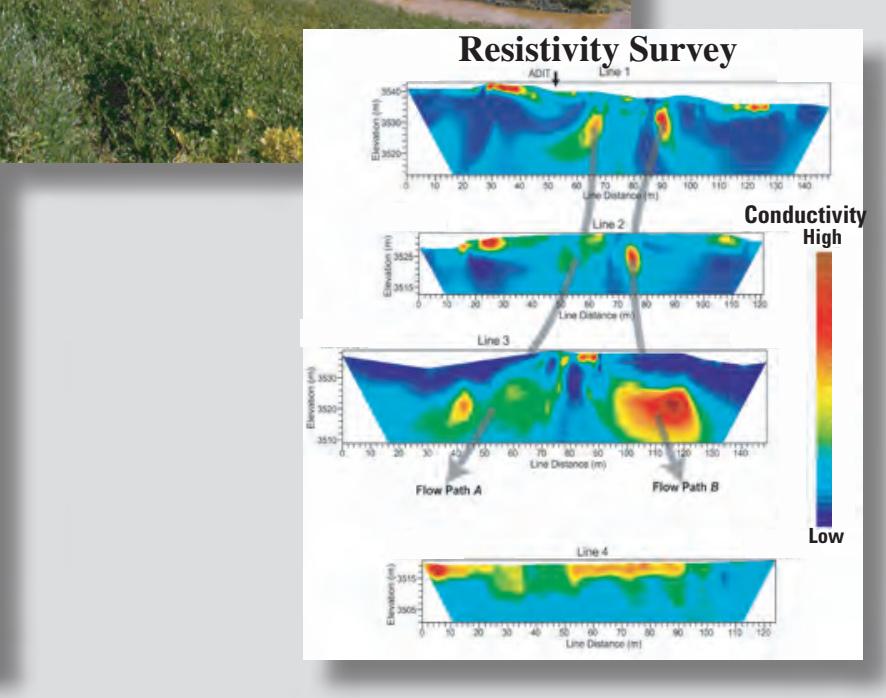

Figure 3. The Waldorf mine, central Colorado, and images showing results from geophysical studies including an electromagnetic survey and resistivity profiles. Brighter colors in graphical images delineate more conductive areas of waste-rock pile, which are interpreted to be water saturated. 
complex hydrogeologic setting; and (c) the upper Animas River watershed in Colorado contains thousands of abandoned mines in an extremely complex hydrogeoloic setting with extensive areas of intense hydrothermal alteration. Time-series data collected as part of the downstream monitoring effort of all three sites (fig. 4) can be used to evaluate the changes in water chemistry that effect the recovery of the aquatic ecosystem. Timeseries data document that in relatively simple hydrogeologic systems success of remedial actions can be observed on a scale of years, but in complex settings, where many natural and anthropogenic sources of metals and acidity are generated, downstream results of remedial actions likely will take longer.

\section{Summary}

The recently completed USGS Mineral Resources Program integrated effort to determine processes that control the release, transport, and fate of contaminants associated with the near-surface weathering of mineral deposits highlights important links between source material and the release of metals and generation of acid. For more information on these and other project-related studies, please visit the project website at http://minerals. cr.usgs.gov/projects/contaminants/index.html. The website includes a detailed description of each study and a complete bibliography.

\section{References}

Allen, H.E., 2002, The biotic ligand model addresses effects of water chemistry on metal toxicity: International Council on Mining and Metals Fact Sheet 7, 5 p.

Caine, J.S., Manning, A.H., Verplanck, P.L., Bove, D.J., Kahn, K.G., and Ge, S., 2006, Well construction information, lithologic logs, water level data, and overview of research in the Handcart Gulch, Colorado-An alpine watershed affected by metalliferous hydrothermal alteration: U.S. Geological Survey Open-File Report 2006-1189, 13 p.

Church, S.E., Choate, L.M., Marot, M.E., Fey, D.L. Adams, M., Briggs, P.H., and Brown, Z.A., 2005, Geochemical assessment of metals and dioxin in sediment from the San Carlos Reservoir and the Gila, San Carlos, and San Francisco Rivers, Arizona: U.S. Geological Survey Scientific Investigations Report 2005-5086, 61 p.

Church, S.E., Owen, J.R., von Guerard, P., Verplanck, P.L., Kimball, B.A., and Yager, D.B., 2007, The effects of acidic mine drainage from historical mines in the Animas River watershed, San Juan County, ColoradoWhat is being done and what can be done to improve water quality?, in DeGraff, J.V., ed., Geological Society of America Reviews in Engineering Geology, v. XVII, p. 47-83.
McDougal, R.R., and Wirt, L., 2007, Characterizing infiltration through a mine-waste dump using electrical geophysical and tracer-injection methods, Clear Creek County, Colorado, in DeGraff, J.V., ed., Geological Society of America Reviews in Engineering Geology, v. XVII, p. 9-24.

\section{For More Information}

Contact:

Philip L. Verplanck

U.S. Geological Survey, MS 973

Denver, CO 80225

Telephone: 303-236-1902

Email: plv@usgs.gov

Stanley E. Church

U.S. Geological Survey, MS 973

Denver, CO 80225

Email: sechurch@usgs.gov

Kathleen S. Smith

U.S. Geological Survey, MS 964D

Denver, CO 80225

Email: kssmith@usgs.gov

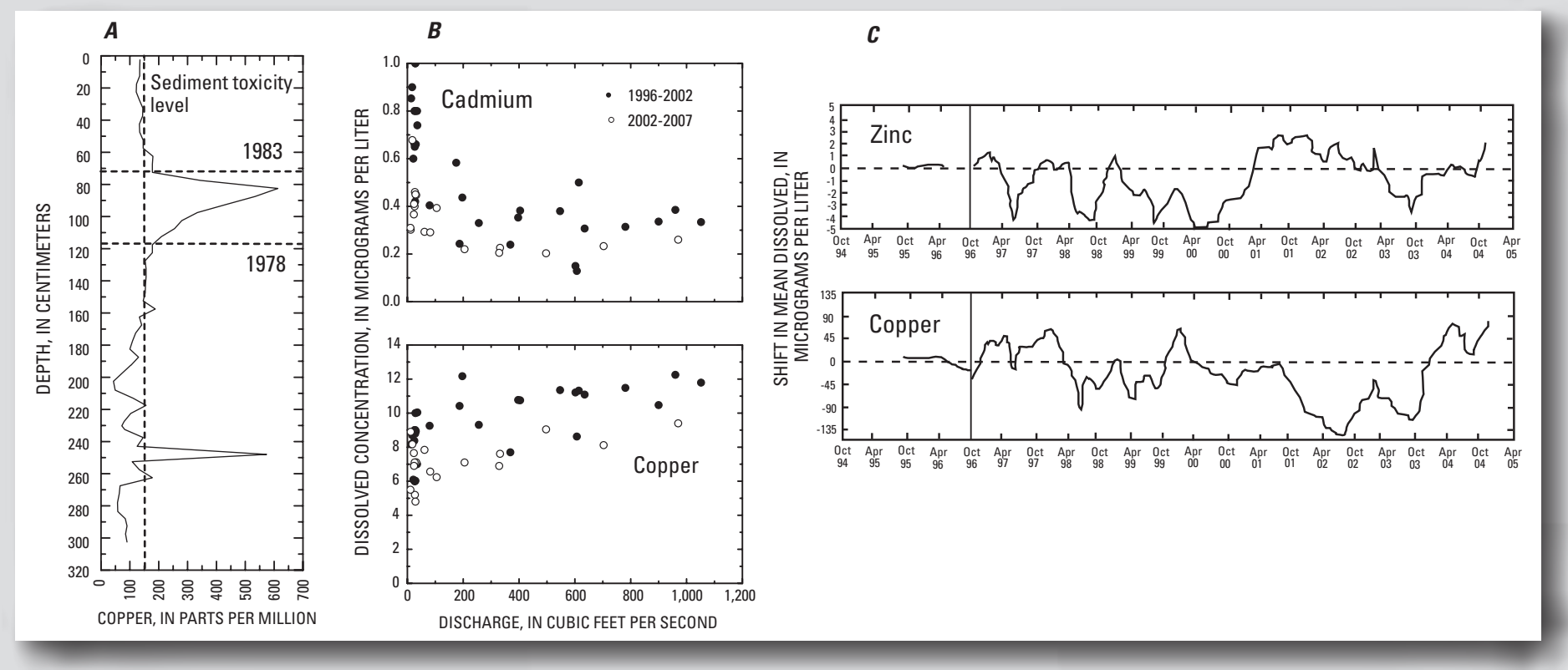

Figure 4. Three examples of time-series data display the extent of post-remediation recovery. $A$, Copper concentrations in sediment from cores collected down stream of the Morenci porphyry copper mine site, Arizona. This plot documents the release of copper from the mine site with peak concentrations from 1978 to 1983 and demonstrates the immediate results of the successful remedial action at the mine site (Church and others, 2005). B, Decrease in dissolved metal concentrations observed after remedial actions (2002-2007) at three small-scale mines and associated fluvial tailings in the Boulder River basin, Montana. C, Time-series water chemistry data for copper and zinc from the upper Animas River downstream of Silverton, Colo. Although substantial remedial efforts have been undertaken within the upper Animas River watershed, only minor improvements in water quality have been achieved after more than a decade of remedial work (Church and others, 2007). 